\title{
Pengaruh Teknologi di Tengah Pandemi Bagi Sosialitas Remaja dalam Perspektif Armada Riyanto
}

\author{
Robertus Syukur ${ }^{1}$, Antonius Denny Firmanto ${ }^{2}$ \\ 1, 2Sekolah Tinggi Filasfat Teologi Widya Sasana Malang \\ Email: ertussyukursmm@gmail.com¹, rm_deni@yahoo.com²
}

\begin{abstract}
Abstrak
Manusia adalah makhluk sosial. Menyadari hakikat ini, tulisan ini bertujuan untuk melihat pengaruh teknologi di tengah pandemi bagi hakikat manusia yang sosialitas dalam perspektif Armada Riyanto. Metode yang digunakan dalam penulisan ini ialah pembacaan kritis. Melihat perkembangan virus corona di Indonesia semakin meningkat, segala kegiatan pun terhambat termasuk proses pendidikan yang kini menuntut penggunaan terknologi, sehingga kebutuhan akan teknologi semakin meningkat. Pengaruh dari teknologi pun akan sangat terasa, terlebih khusus di kalangan masyrakat yang sebelumnya jarang atau bahkan belum mengenal teknologi. Dampak dari penggunaan teknologi sangat bersentuhan langsung dengan hakikat manusia yang sosialitas. Sosialitas dalam pandangan Armada Riyanto ialah menjadi sesama bagi sesama yang terungkap nyata dalam kehidupan konkret atau dengan kata lain sosialitas manusia ada dalam kesehariannya. Pandangan ini mengungkapkan kejelasan mengenai hakikat manusia yang mestinya sosialitas. Pengaruh teknologi terhadap hakikat manusia yang sosialitas ini pun terlihat sangat jelas. Ada pengaruh yang baik dan ada pula pengaruh yang kurang baik bagi hakikat manusia yang memiliki sifat sosialitas.
\end{abstract}

Kata kunci: komunikasi; perubahan sosial; interaksi.

\begin{abstract}
Humans are social creatures. With this essence, this paper aims to see the influence of technology in the midst of a pandemic for the nature of human sociality in the perspective of Fleet Riyanto. The method used in this writing is critical reading. Seeing the development of the corona virus in Indonesia is increasing, all activities are hampered including the educational process which now demands the use of technology, so the need for technology will increase. The influence of technology will also be felt, especially among people who previously rarely or even did not know technology. The impact of the use of technology is very direct with the nature of human sociality. Sociality in Fleet Riyanto's view is being a fellow fellow who is revealed in real life or in other words, human sociality exists in his daily life. This view reveals the nature of humans who view sociality. The influence of technology on the nature of human sociality is also very clear. There is a good influence and there is also a bad influence on human nature which has the nature of sociality.
\end{abstract}

Keywords: communication; social transformation; interaction.

\section{Pendahuluan}

Dalam kehidupan sehari-hari ada faktor-faktor yang memengaruhi perubahan sosial dan sosialitas manusia. Salah satunya ialah faktor teknologi. Adanya penemuan teknologi memberi perubahan pada kehidupan sosial dan sosialitas manusia, apalagi salah satu agen sosialisasi adalah media massa, dan media massa ini digunakan oleh begitu banyak orang dan media massa pulalah yang telah menghanyutkan manusia dalam kepentingannya masing-masing. Hal ini membuat manusia lupa dengan hakikatnya sebagai makhluk sosial yang tentunya memiliki sifat sosialitas yang tinggi (Raharjo, 2009).

Manusia adalah makhluk sosial. Menyadari hakikat ini, manusia tidak dapat berjalan sendiri. Sebagai makhluk sosial, dalam dirinya sudah terkandung sifat sosialitas yang merupakan hakikatnya juga. Sosialitas yang ada dalam diri manusia itu mesti diaktualisasikan dengan cara membangun relasi dengan orang lain. Relasi itu juga memberi manfaat bagi kehidupannya yaitu mampu memenuhi kebutuhan hidup. Relasi yang dibentuk itu membuat pemikiran manusia semakin berkembang, sehingga manusia mampu menciptakan teknologi (Laksami, 2017). Selain relasi, perkembangan ilmu pengetahuanpun memberi pengaruh terhadap proses kelahiran dan perkembangan teknologi. Kini teknologi yang diciptakan itu telah berkembang dan tersebar ke 
seluruh dunia. Indonesia pun terjangkau oleh alat-alat teknologi tersebut. Penyebarannya di Indonesia tidak hanya di daerah perkotaan, tetapi juga terjangkau hingga ke pelosok-pelosok daerah. Apalagi dengan situasi sekarang ini yaitu pandemi virus corona. Situasi ini tentu menuntut semua pribadi menggunakan alat-alat teknologi, teristimewa orang-orang yang mempunyai tugas yang baik secara langsung maupun tidak langsung bergelut dengan alat teknologi tersebut. Misalnya pelajar, guru, pegawai kantoran, pengusaha, dan lain sebagainya. Namun tidak menutup kemungkinan yang lain tidak menggunakan alat teknologi. Karena tuntutan ini penyebaran alat-alat teknologi semakin meningkat. Perkembangan dan penyebaran alat-alat teknologi ini tentunya mempunyai dampak pada tatanan hidup masyarakat. Entah tatanan hidup ekonomi, politik, maupun sosial. Pengaruh yang disorot dalam tulisan ini ialah pengaruh pada tatanan hidup sosial teristimewa menyangkut sosialisasi yang ada dalam diri setiap pribadi, yaitu memandang sesama sebagai sesama yang tidak hanya terungkap dalam kebersamaan badani atau kebersamaan secara fisik, tetapi juga terungkap dalam komunikasi.

Perkembangan zaman semakin pesat. Permintaan alat teknologi terus meningkat. Penyebaran alat teknologi ke setiap daerah pun begitu mudah. Kehadiran pandemi ini mendorong kita untuk melangkah lebih cepat terhadap penggunaan teknologi.

Dunia zaman sekarang dipenuhi dengan teknologi. Manusia pun tidak dapat tidak hidup di dalam dunia teknologi dan harus menerima realita ini. Apabila kita tidak menggunakan teknologi atau mengalami dunia tanpa teknologi justru dianggap aneh. Maka perlu pembedaan antara dunia yang dialami melalui teknologi dan dunia yang dialami tanpa teknologi demikianpun halnya dengan perbedaan antara masyarakat yang banyak menggunakan teknologi dan masyarakat yang sedikit mengalami atau menggunakan teknologi (Francis Lim, 2008).

Masyarakat yang belum mengenal teknologi masih mempunyai sifat sosialitas yang tinggi dan begitupun sebaliknya yaitu masyarakat yang sudah mengenal teknologi sifat sosialitasnya sudah mulai menurun. Hal ini dapat dilihat dari kehidupan sehari-hari. Misalkan saja dua orang yang masing-masing memegang gawai pasti tidak berkomunikasi karena mereka saling bergelut dengan gawainya masing-masing. Hal ini membuat manusia yang jauh terasa dekat dan manusia yang dekat terasa jauh (Iskandar, 2018). Kebiasaan ini pun akan membuat hubungan antara manusia atau sifat sosialitas yang ada dalam diri manusia semakin berkurang. Masalah yang dibahas dalam tulisan ini ialah bagaimana masyarakat melakukan komunikasi terhadap sesama dan apa sarana yang digunakan dalam membentuk komunikasi itu? Apakah teknologi itu mengubah kehidupan manusia yaitu memberikan nilai positif ataukah sebaliknnya memberikan nilai negatif?

Armada Riyanto telah mengulas dengan sangat baik dalam menjelaskan hakikat manusia yang memiliki sifat sosialitas. Sosialitas dalam pandangan Armada Riyanto ialah melihat sesama sebagai "aku" yang lain. Sosialitas bukan berarti "kebersamaan" materi badan, seperti duduk bersama atau semacam itu. Sosialitas sesungguhnya produk dari keseharain hidup manusia. Sosialitas itu bukan abstraksi mengenai manusia yang diciptakan oleh Sang Pencipta. Tetapi, sosialitas manusia terdapat dalam kesehariannya. Bila dalam kehidupan sehari-hari manusia tidak menampilkan hakikatnya berarti manusia itu berada dalam ketersebunyian sosialitasnya (Riyanto, 2013).

\section{Metode}

Penelitian ini merupakan penelitian deskriptif kualitatif, di mana hasil dari penelitian ini berusaha untuk menjelaskan keadaan yang dijadikan objek penelitian. Dalam penelitian ini peneliti berpedomaan pada tahapan penelitian kualitatif sebagaimana yang disampaikan oleh John Cresswell. Menurutnya ada kurang lebih enam tahapan penelitian kualitatif, yaitu; 1) dimulai dengan mengindentifikasi masalah yang menjadi sasaran dalam penelitian, 2) pembahasan atau penelusuran kepustakaan (literature review), 3) menentukan tujuan penelitian, 4) pengumpulan data, 5) analisis dan penafsiran data, dan 6) laporan (Raco, 2010).

Dalam penelitian, penulis menggunakan teknik wawancara tidak langsung dengan mengajukan kuisioner yang disebarkan mengunakan media google form. Analisis menggunakan tiga alur kegiatan yang terjadi secara bersamaan yaitu: reduksi data, penyajian data, dan penarikan kesimpulan. 


\section{Hasil dan Pembahasan \\ a. Proses Komunikasi dan Sarana yang Digunakan}

Manusia adalah makhluk sosial. Sebagai makhluk sosial, manusia sangat perlu untuk berinteraksi dan berkomunikasi dengan manusia lain yang ada di sekitarnya guna memenuhi kebutuhan hidupnya (Imrah, 1999). Menyadari hakikat ini manusia tidak dapat berdiri sendiri melainkan ia membutuhkan kehadiran orang lain di sekitarnya. Kehadiran pribadi yang lain akan terbentuk komunikasi. Apalagi menyadari salah satu kodrat manusia yaitu makhluk yang komunikatif. Seluruh tubuh manusia mampu berkomunikasi, yaitu komunikasi yang dilakukan dengan gerak badan dan komunikasi dengan vokal. Komunikasi itu akan terjalin dengan baik, apabila kedua belah pihak bisa saling mengerti akan keberadaan sesama dan mengerti dengan keberadaan diri sendiri. Ketika seorang pribadi mampu mengerti dan memahami keinginan dirinya, mampu memahami keinginan orang lain, maka akan tercipta suatu komunikasi yang harmonis, baik, dan tidak adanya konflik dalam kehidupan bersama. Selain itu, dalam komunikasi pula seorang pribadi mesti mengedepankan hakikatnya sebagai makhluk sosial yang memiliki kodrat sosialitas. Semua tindakan komunikasi adalah sebuah proses. Proses ini tentu mencakup beberapa hal seperti sumber, pesan dan cara menerima pesan. Ketika alat teknologi mampu menciptakan komunikasi, maka terjadilah sebuah proses. Faktor-faktor yang memengaruhi komunikasi akan memengaruhi isi dan reprentasi pesan dari sebuah proses. Jika proses mencakup ide tentang pesan, maka ide tersebut mencakup tentang makna (Burton, 2008).

Manusia adalah makhluk yang terus membutuhkan kehadiran orang lain di sekitarnya. Kehadiran orang lain akan sangat dihargai oleh orang lain pula. Proses saling menghargai ini akan berdampak pada komunikasi yang harmonis. Dalam buku ajaran komunikasi kesehatan mengatakan hubungan manusia dapat berjalan selaras, harmonis, lancar, dan sesuai dengan harapan, apabila memerhatikan dua syarat berikut: pertama, ada unsur simpati dan empati yang ditandai dengan saling memberi perhatian, sehingga menjalin interaksi yang baik dan komunikasi yang berjalan lancar. Kedua, paham akan kebutuhan manusia. Setiap pribadi pasti mempunyai kebutuhan hidupnya. Kehadiran orang di sekitar mesti mampu memahami kebutuhan itu dan berusaha membantu pribadi tersebut untuk memenuhi kebutuhan hidupnya (Reni Agustina Harahap, 2019). Selain itu, kehidupan sosial terasa sangat harmonis, damai, tentram, dan bahagia bila adanya komunikasi yang baik. Komunikasi yang baik dapat dibentuk bila setiap pribadi memiliki pengetahuan mengenai komunikasi yang baik. Menurut Hendropuspito dalam buku sosiologi agama mengatakan bahwa pribadi yang mampu berkomunikasi dengan baik ialah: pertama, pribadi yang dialogal. Pribadi yang dialogal dalam pandangan Reuel L. Howe adalah pribadi yang memiliki sifat utuh dan otentik. Pribadi yang utuh ialah pribadi yang sungguhsungguh hadir dalam proses komunikasi, ia memberikan diri seutuhnya kepada orang yang berbicara kepadanya. Pribadi yang otentik ialah pribadi yang melihat orang yang berbicara kepadanya sebagai pribadi. Selanjutnya adalah pribadi yang terbuka. Artinya, ia menampilkan diri apa adanya bersedia mendengar dan menerima ungkapan diri dari orang lain, bahkan apabila ungkapan itu berupa kritikan. Ketiga, pribadi yang disiplin. Artinya, pribadi tersebut sungguhsungguh menghargai tata tertib yang dibuat untuk terciptanya suatu komunikasi yang harmonis. Kedua, pribadi yang mampu melihat dan memahami hal-hal yang menyebabkan proses komunikasi tidak dapat berjalan dengan lancar, baik, dan harmonis. Artinya pribadi tersebut mesti menyadari segala sesuatu yang membuat komunikasi "rusak", seperti rintangan bahasa, gambaran tentang orang lain yang keliru, dan nafsu membela diri. (Hendropuspito, 1983). Seorang pribadi yang hendak membangun komunikasi yang harmonis, lancar, dan baik, mesti paling kurang memiliki kualitas pribadi seperti yang diuraikan di atas.

Komunikasi dapat dilakukan dengan berbagai cara dan dapat menggunakan berbagai sarana. Sarana-sarana yang ada mesti menghantar manusia pada komunikasi yang baik dan membentuk manusia menjadi pribadi yang mampu mengungkapkan kodrat sosialitasnya. Sarana-sarana yang digunakan pun mesti membuat pribadi manusia menjadi lebih dewasa dalam berkomunikasi. Pribadi yang dewasa dalam berkomunikasi adalah pribadi yang sungguhsungguh mampu memperhatikan syarat-syarat dalam berkomunikasi. Selain itu, dewasa juga adalah pribadi yang sungguh-sungguh mampu mengungkapkan kontrak sosialitasnya dalam kehidupan konkrit. Menurut Agus M. Hardjana dalam buku komunikasi intrapersonal dan interpersonal mengungkapkan komunikasi dapat dilakukan dengan menggunakan beberapa media seperti media lisan, media tertulis, dan media elektronik. Tentu ketiga media ini mempunyai keuntungannya masing-masing (Hardjana, 2003). Selain keuntungan terkandung juga kerugiannya terlebih khusus bagi kodrat sosialitas manusia. Melihat media-media yang tersedia disadari bahwa media sosial pun menjadi salah satu agen sosialisasi dalam kehidupan. Hubungan sosial yang baik ialah ketika merasa nyaman dengan diri sendiri dan dengan orang 
lain, begitupun sebaliknya. Hubungan sosialisasi yang baik karena adanya komunikasi yang baik dari kedua belah pihak. Keberhasilan komunikasi bukan hanya pembicaraan tetapi juga pendengar.

Manusia adalah pribadi yang mampu beradaptasi dengan lingkungan dan situasi yang terjadi di sekitarnya. Manusia menggunakan pikiran untuk dapat menempatkan diri dalam lingkungan sosial. Kemampuan ini terungkap dalam interaksi sosial baik secara verbal maupun secara non-verbal (Ibda, 2018). Keberadaan manusia terungkap dalam interaksi sosial dan kehangatan dalam berkomunikasi. Komunikasi yang dibangun mesti melampau ruang dan waktu atau melewati sekat-sekat perbedaan. Apalagi menyadari keberadaan bangsa Indonesia sebagai bangsa yang majemuk dan memiliki banyak suku, ras, agama, dan golongan. Keberagaman tersebut menjadi sangat indah ketika komunikasi yang dibangun mengedepankan sikap rendah hati dan mengutamakan sifat sosialitas manusia. Dalam buku Aku dan Liyan yang ditulis oleh Armada Riyanto mengatakan sebagai berikut.

Sosialitas yang ideal hanya bisa tercapai apabila sosialisasi itu tidak terbagi dalam kelas kelas masyarakat. Sosial itas yang ideal itu, mengenakan manusia aku bisa memenuhi kebutuhannya tanpa harus diperbudak oleh kaum yang berkuasa dalam hal ini iyalah para intelektual yang menghasilkan alat teknologi. Kehidupan sosial seharusnya mendasarkan diri pada kebaikan sebagai tujuan bersama. Maksudnya ialah mengedepankan transendensi manusia dan kebaikan bersama sebagai tujuannya. (Armada Riyanto, 2011).

Ungkapan tersebut menekankan unsur kebebasan manusia dalam mengambil sebuah keputusan, tentunya tetap memerhatikan kebaikan bersama. Kebebasan manusia yang bertanggung jawab adalah salah satu kodrat manusia. Kebebasan yang bertanggungjawab menjadi kekhasan atau keunggulan manusia jika dibandingkan dengan makhluk lainnya. Manusia pun mesti mempunyai kesadaran akan kekhasan tersebut. Kesadaran itu akan menjadi pegangan setiap pribadi. Pribadi yang mempunyai pegangan akan menjadi lebih kuat terhadap pengaruh perkembangan alat teknologi. Armada Riyanto dalam buku Menjadi-Mencintai mengungkapkan sebagai berikut.

Kesadaran mengatakan subjektivitas. Subjektivitas di sini ialah menyangkut konteks etika. Dalam etika subjektivitas berarti kehendak dan keputusan menjadi milikku. Subjektivitas menjadi prasyarat tindakanku disebut tindakan manusiawi. Subjektivitas memaksudkan aku memiliki segalanya untuk bertanggung jawab atas tindakanku. Subjektivitas identik dengan kebebasanku (Armada Riyanto, 2013).

Ungkapan sederhana ini menunjukkan suatu kebebasan yang bergantung pada diri sendiri. Ketika setiap pribadi sudah mampu menyadari kebebasan seperti ini, maka akan minim pengaruh teknologi bagi kehidupan manusia teristimewa menyangkut hakikat manusia yang sosialitas. Kesadaran menjadi nilai penting dalam kehidupan sosial. Namun, kerap kali terjadinya kehilangan kesadaran. Ketidaksadaran ini terjadi ketika manusia tidak berada dalam kapasitas mengatur dan mengolah hidupnya dengan baik. Ketidaksadaran ini pula akan membuat sosialitas manusia lambat laun akan tumpul. Ketumpulan inilah yang membuat manusia menciptakan persoalan dalam kehidupan bersama. Artinya, adanya relasi yang kurang baik antar pribadi, apalagi hadirnya alat teknologi yang membuat manusia merasa nyaman atau dengan kata lain alat teknologi menjadi tempat pelarian setiap pribadi yang merasa tidak nyaman dengan diri sendiri dan dengan orang lain.

Hakikat manusia yang sosialitas memiliki karakter yang dialogal karena manusia hidup bersama orang lain. Ketika manusia hidup, ia ada bersama dengan sesamanya. Dialogaliltas sangat bersentuhan langsung dengan hakikat sosialitas manusia dan tentunya akan keberadaan orang lain (Riyanto, 2009). Melihat situasi yang terjadi dalam kehidupan sehari-hari yaitu begitu banyak manusia teristimewa kaum muda yang sangat mudah terbawa arus zaman. Kehadiran alat teknologi memberi perubahan yang sangat besar terhadap hakikat manusia yang sosialitas. Armada Riyanto mencoba menjelaskan dan tentunya mengingatkan kembali kaum muda akan hakikatnya sebagai makhluk sosial yang memiliki hakikat sosialitas dan tentunya yang bersentuhan langsung dengan sikap dialog. Armada menjelaskan dengan terperinci mengenai hakikat manusia tersebut. Namun, ketika melihat realitas yang terjadi dalam kehidupan zaman sekarang tentunya apa yang telah diulas baik oleh Armada tidak memberi pengaruh besar bagi kehidupan kaum mudah.

Kebebasan manusia membuat manusia dapat melakukan sesuatu yang diinginkan. Armada menjelaskan bahwa kebebasan bersumber dari diri sendiri. Tentuya manusia mesti 
mampu menyadari hal tersebut dan mengenalinya dengan sangat baik. Proses pengenalan diri ini memberi pengaruh yang besar terhadap kehidupan manusia teristimewa terhadap hakikat manusia yang sosialitas dan erat kaitanya dengan dialog.

Kehadiran alat teknologi yang memberi pengaruh terhadap kehidupan manusia tentunya karena manusia belum menemukan kebebasan sejati yang berasal dari diri sendiri. Kaum muda yang terjerumus dalam pengaruh alat teknologi ini tentunya secara tidak langsung "menyangkal" keberadaannya sebagai makhluk sosial yang sosialitas. Armada mengatakan ketika manusia mengurung diri dan hanya sibuk dengan diri sendiri maka manusia tersebut semakin tidak manusiawi. Karena, mengurungi diri dan hanya berkutat dengan diri sendiri berarti dia menyangkal keberadaan dan peran dari sesamanya yang lain (Riyanto, 2009).

\section{b. Teknologi dalam Kehidupan Manusia}

Perkembangan zaman semakin pesat. Perkembangan ini terlihat dari banyaknya alat teknologi yang diciptakan oleh manusia dan semakin berkembangnya proses berpikir dari manusia. Perkembangan alat teknologi yang pesat terjadi karena berkembangnya atau semakin majunya proses berpikir manusia. Perkembangan alat teknologi informasi yang pesat tentunya mengubah tabiat setiap orang yang ada di dalamnya yaitu yang hidup dan menggunakan alat teknologi. Generasi pun berubah senada dengan perkemabnagan zaman. Perkembangan ini tentu mengubah cara berperilaku setiap orang dalam berkomunikasi dan menjalin relasi dengan orang lain terutama yang ada di sekitar. Zainuddin Maliki dalam buku rekonstruksi teori sosial modern mengatakan, perkembangan ilmu pengetahuan dan teknologi telah mengubah cara berpikir masyarakat, perubahan itu terutama dalam memahami realitas kehidupan, baik budaya, sosial, ideologi, agama maupun politik. Nilai-nilai lama yang sudah menjadi pegangan dan mengakar tercabut seketika, namun pegangan atau nilai-nilai baru yang belum bisa berakar kuat justru meraja dalam diri manusia. Peristiwa ini pun menimbulkan situasi kekacauan dalam tatanan hidup masyarakat dan dengan sendirinya nilai sosialitas dari setiap pribadi yang merupakan kodrat dari manusia itu hilang (Maliki, 2018). Perbadaan mestinya menyatukan bukan memecahbelahkan masyarakat.

Menjadi tidak wajar ketika perbedaan itu dimaknai sebagai alasan keterpecahan satu sama lain. Dan, sering kali bukan hanya keterpecahan yang terjadi, melainkan konflik, perang, dan saling meniadakan. Petumpahan darah karena perbedaan tersebut mengatakan absurditas pada tataran hermeneutika. (Armada Riyanto, 2018).

Perkembangan teknologi sesungguhnya tidak memberikan perubahan pada kehidupan dan tatanan hidup masyarakat. Perubahan yang terjadi pada manusia karena teknologi disebabkan oleh manusia tersebut tidak mempunyai pegangan atau tidak mempunyai prinsip dalam menggunakan alat-alat teknologi. Karena sesungguhnya teknologi bersifat netral. Artinya teknologi tidak memberikan perubahan atau efek pada kehidupan manusia. Tetapi manusialah yang mengubah kenetralan dari teknologi tersebut (Francis Lim, 2008). Keberadaan alat teknologi sesungguhnya tidak mengancam keberadaan manusia dan tentunya tidak mematikan kodrat sosialitas manusia. Proses modernisasi yang ditunjukkan dengan munculnya penemuan ilmu-ilmu pengetahuan dan teknologi, telah menyumbangkan sistem sosial yang menjaga keutuhan masyarakat dan mengungkapkan sosilaitas yang menjadi hakikat dasar manusia. (Hardiman, 2003).

Manusia disebut sebagai makhluk sosial karena setiap manusia mutlak tergantung atau berharap pada orang lain. Tidak seorangpun yang tidak bergantung pada orang lain. Seseorang dikatakan dewasa secara sosial bila mampu bekerjasama dengan semua orang. Disinilah tampak secara realitas dan jelas dari sosialisasi manusia (Toeniloe, 2016). Begitu pula dalam dunia sosial ialah dunia yang terbuka terhadap perkembangan teknologi. Bagi Habermas perkembangan teknologi tidak mengancam keberadaan manusia, tetapi memberi gangguan pada manusia teristimewa aspek komunikatif dan sosialitas yang ada dalam diri manusia (Lim, 2008). Kehadiran alat teknologi mesti menumbuhkan sikap konsisten terhadap diri sendiri. Agar kehadiran alat teknologi tidak memberikan gangguan sedikitpun terhadap kodrat komunikatif dan sosialisasi dari manusia.

Manusia memiliki sifat sosialitas karena ada sifat individualitas. Individu adalah seorang pribadi yang memiliki kekhasan dari individu yang lain. Keberadaan individu dalam kehidupan masyarakat mempunyai tujuan, salah satu tujuannya ialah membentuk diri agar bisa berkembang menjadi lebih baik. Untuk mencapai hal tersebut individu mesti menjalin relasi dan mengasah hakikat sosialitasnya (Irawan dan Indradin, 2016). Konsep diri dapat berkembang seiring perjalanan waktu teristimewa bertambahnya pengalaman dan pengetahuan serta kemajuan 
teknologi yang diperoleh melalui interaksi dengan individu lain dan interaksi dengan lingkungan. (Temaluru, 2019). Relasi dengan orang lain inilah yang mengungkapkan hakikat sosilaitas manusia.

Kehadiran alat teknologi memang tidak mengancam keberadaan manusia. Namun, kehadiran alat teknologi memberikan dampak positif dan negatif bagi sosialitas manusia. Dampak positifnya ialah: pertama, memiliki banyak teman dan kenalan. Kedua, mampu membangun relasi dengan siapapun dan dimana pun keberadaan orang tersebut. Setiap orang mampu berinteraksi antarpribadi melalui jaringan internet yang akan menciptakan jejaringan sosial yang begitu memukau. Hal ini pun, membuat atau menciptakan parstisipasi publik yang luas dan besar, tanpa dibatasi oleh ruang, waktu, status, dan usia karena mempunyai daya tawar yang sangat luar biasa. Kehadiran alat teknologi ini membuat atau menciptakan suatu dunia virtual (maya). Fenomena ini, segala sesuatu seakan-akan terlihat nyata, sebagai suatu kentyataan yang sebenarnya, namun itu bisa saja hanya rekaan semata yang dapat menghipnotis para pengguna alat teknologi. Ketiga, membuat manusia yang jauh terasa dekat. Hal ini bisa menyentuh siapa pun. Namun, tidak bisa dipungkiri hal ini juga dapat membuat manusia tertipu. Ini disebabkan karena adanya akun yang palsu yang tidak menampilkan diri apa adanya. Ketika hal ini tejadi maka akan terciptanya suatu hubungan yang tidak baik dan bahkan membuat alat teknologi itu kehilangan makna yang sesungguhnya. Keempat, meningkatkan sikap kepekaan sosial terhadap situasi dunia. Hal ini terungkap dalam situasi sekarang ini yaitu pandemi virus corona. Di tengah situasi seperti ini, jangan sampai manusia, demi menyelamatkan diri dan keluarganya alpa pada sesama, tetapi dituntut secara moral untuk tetap menunjukkan kepedulian kepada sesama, berbela rasa terhadap para pasien, memberikan penghormatan kepada para petugas kesehatan yang telah mengorbankan diri untuk merawat mereka, dan mengantar ke tempat peristirahatan. Dampak negatifnya ialah: pertama, melemahnya sosialitas manusia. Artinya manusia sibuk dengan dirinya sendiri, apalagi jika manusia tersebut sudah dengan handphone masing-masing. Kedua, membuat manusia yang dekat terasa jauh. Artinya, manusia sibuk membangun hubungan sosial dengan orang yang keberadaaanya sangat jauh (didekatkan oleh alat teknologi yaitu melalaui media massa), tetapi lupa dengan orang yang ada di sekitarnya. Orang yang di sekitar akan merasa sendiri, kendati secara fisik mereka ada bersama. Namun, secara sosilaitas mereka tidak bersama karean tidak ada komunikasi antarpribadi. Ketiga, mampu mencuci atau memengaruhi kepribadian seseorang yaitu terciptantya suatu mentalitas instan yang membuat manusia kehilangan hakihat dasarnya. Selain hal-hal di atas, Leo Sugiyono dalam buku hidup di era digital mengatakan perkembangan alat teknologi membuat dan menciptakan revolusi dalam berkomunikasi, apalagi setelah muncul dan berkembangnya internet. Maka, terjadi interaksi yang begitu memengaruhi orang. (Sugiyono, 2015). Revolusi dalam berkomunikasi ini, tentunya lebih banyak membuat manusia kehilangan hakikat sosialitas.

Setelah melakukan wawancara lewat media sosial dan lewat google form, didapatkan hasil seperti berikut.

Tabel 1. Hasil Wawancara

\begin{tabular}{cccccc}
\hline NoP & Sangat tidak setuju & Tidak setuju & Cukup & Setuju & Sangat setuju \\
\hline 1 & $12,7 \%$ & $6,9 \%$ & $28,4 \%$ & $20,6 \%$ & $31,4 \%$ \\
\hline 2 & $17,6 \%$ & $17,6 \%$ & $22,6 \%$ & $13,7 \%$ & $28,4 \%$ \\
\hline 3 & $4,9 \%$ & $2,5 \%$ & $15,7 \%$ & $21,6 \%$ & $54,9 \%$ \\
\hline 4 & $6,9 \%$ & $0 \%$ & $1 \%$ & $6,9 \%$ & $85,3 \%$ \\
\hline 5 & $29,4 \%$ & $21,6 \%$ & $26,5 \%$ & $7,8 \%$ & $14,7 \%$ \\
\hline 6 & $4,9 \%$ & $2 \%$ & $3,9 \%$ & $11,8 \%$ & $77,5 \%$ \\
\hline 7 & $36,3 \%$ & $22,5 \%$ & $20,6 \%$ & $13,7 \%$ & $6,9 \%$ \\
\hline 8 & $32,4 \%$ & $20,6 \%$ & $23,5 \%$ & $10,8 \%$ & $12,7 \%$ \\
\hline 9 & $37,3 \%$ & $20,6 \%$ & $20,6 \%$ & $12,7 \%$ & $8,8 \%$ \\
\hline 10 & $3,9 \%$ & $7,8 \%$ & $38,2 \%$ & $22,5 \%$ & $27,5 \%$ \\
\hline 11 & $6,6 \%$ & $3,9 \%$ & $27,5 \%$ & $26,5 \%$ & $35,3 \%$ \\
\hline 12 & $2 \%$ & $6,9 \%$ & $29,4 \%$ & $19,6 \%$ & $42,2 \%$ \\
\hline 13 & $2,9 \%$ & $2 \%$ & $4,9 \%$ & $12,7 \%$ & $77,5 \%$ \\
\hline 14 & $4,9 \%$ & $2 \%$ & $23,7 \%$ & $17,6 \%$ & $61,8 \%$ \\
\hline 15 & $4,9 \%$ & $6,9 \%$ & $15,7 \%$ & $18,6 \%$ & $53,8 \%$ \\
\hline
\end{tabular}

NoP: Nomor Pernyataan 
Keterangan:

1. Alat teknologi membuat saya lupa waktu

2. Alat teknologi membuat saya masa bodoh

3. Alat teknologi mendekatkan yang jauh dan menjauhkan yang dekat

4. Alat teknologi membantu saya mengetahui perkembangan zaman

5. Alat teknologi membuat saya tuli terhadap jeritan orang di sekitar

6. Alat teknologi membantu saya dalam banyak hal

7. Alat teknologi membuat saya jenuh

8. Saya menggunakan alat teknologi hanya untuk hiburan semata

9. Alat teknologi membuat saya merasa sendiri

10. Alat teknologi membuat saya bahagia

11. Alat teknologi sesungguhnya bersifat netral

12. Manusia mengubah kenetralan alat teknologi

13. Alat teknologi menambah wawasan dan pengetahuan

14. Alat teknologi membuat saya banya teman

15. Saya senang menggunakan alat teknologi dalam pengawasa orang tua

Data hasil goole form yang ditampilkan di atas hendak saya bagikan menjadi dua. Pernyataan 9-15 mengungkapkan masalah pertama yang hendak saya bahas yaitu bagaimana masyrakat melakukan komunikasi dan sarana yang digunakan untuk membentuk komunikasi tersebut. Pernyataan 1-8 mengungkapkan masalah yang kedua yaitu menyangkut dengan pengaruh alat teknologi bagi kehidupan manusia. Data peryataan 9-15 menjelaskan mayarakat sekarang melakukan dan membentuk komunikasi yang sangat baik dengan sesama manusia, dan sarana yang digunakan untuk menunjang komunikasi yang baik itu ialah dengan mengguanakan alat teknologi. Alat teknologi yang dihasilkan oleh pikiran manusia telah membantu manusia pula dalam berkomunikasi. Apalagi hakikat manusia sebagai makhluk sosial. Menyadari hakikat ini, manusia tidak dapat berdiri sendiri melainkan ia membutuhkan kehadiran orang lain di sekitarnya. Kehadiran pribadi yang lain akan terbentuk komunikasi. Apalagi menyadari salah satu kodrat manusia yaitu makhluk yang komunikatif. Seluruh tubuh manusia mampu berkomunikasi, yaitu komunikasi yang dilakukan dengan gerak badan dan komunikasi dengan vokal. Komunikasi itu akan terjalin dengan baik, apabila kedua belah pihak bisa saling mengerti akan keberadaan sesama dan mengerti dengan keberadaan diri sendiri. Ketika seorang pribadi mampu mengeri dan memahami keinginan dirinya dan mampu memahami keinginan orang lain maka akan terciptanya suatu komunikasi yang harmonis dan tidak adanya konflik dalam kehidupan bersama. Selain itu, dalam komunikasi pula seorang pribadi mesti mengedepankan hakikatnya sebagai makhluk sosial yang memiliki kodrat sosialitas. Alat teknologi pula sangat membantu manuisa berkomunikasi dengan sesamanya teristimewa dengan orang yang posisinya berjauhan dengan sesama. Hal ini menunjukan nilai baik dari alat teknologi tersebut. Namun, kebaikan sesuatu tidak terlepas dari nilai kurang baiknya pula terlebih khusus alat teknologi bagi kehidupan manusia teristimewa bagi sosilaitas manusia. Dengan kata lain, selain keuntungan terkandung juga kerugiannya terlebih khusus bagi kodrat sosialitas manusia. Melihat media-media yang tersedia disadari bahwa media sosial pun menjadi salah satu agen sosialisasi dalam kehidupan. Hubungan sosial yang baik ialah ketika merasa nyaman dengan diri sendiri dan dengan orang lain, begitupun sebaliknya. Hubungan sosialisasi yang baik karena adanya komunikasi yang baik dari kedua belah pihak. Keberhasilan komunikasi bukan hanya pembicaraan tetapi juga pendengar. Melihat data yang ditampilakan di atas mengungkapakan bahwa pengaruh negatif alat teknologi bagi kehidupan sosialitas manusia sangat besar jika dibandingkan dengan pengaruh positifnya bagi kehidupan sosilaitas manusia. Kehadiran alat teknologi memang tidak mengancam keberadaan manusia. Namun tetap memiliki pengaruh negatif bagi kehidupan sosialitas manusia. Dampak negatifnya ialah: pertama, melemahnya sosialitas manusia. Artinya manusia sibuk dengan dirinya sendiri, apalagi jika manusia tersebut sudah dengan handphone masing-masing. Kedua, membuat manusia yang jauh terasa dekat. Artinya, manusia sibuk membangun hubungan sosial dengan orang yang keberadaaanya sangat jauh (didekatkan oleh alat teknologi yaitu melalaui media massa), tetapi lupa dengan orang yang ada di sekitarnya. Orang yang di sekitar akan merasa sendiri, kendati secara fisik mereka ada bersama. Namun, secara sosilaitas mereka tidak bersama karena tidak terciptanya komunikasi.

Kesadaran menjadi nilai penting dalam kehidupan sosial. Namun, kerap kali terjadinya kehilangan kesadaran. Ketidaksadaran ini terjadi ketika manusia tidak berada dalam kapasitas mengatur dan mengolah hidupnya dengan baik. Ketidaksadaran ini pula akan membuat sosialitas 
manusia lambat laun akan tumpul. Seorang pribadi juga dituntut menjadi pribadi yang dewasa dalam mengunakan alat teknologi dan berkomunikasi. Komunikasi dapat dilakukan dengan berbagai cara dan dapat menggunakan berbagai sarana. Sarana-sarana yang ada mesti menghantar manusia pada komunikasi yang baik dan membentuk manusia menjadi pribadi yang mampu mengungkapkan kodrat sosialitasnya. Sarana-sarana yang digunakan pun mesti membuat pribadi manusia menjadi lebih dewasa dalam berkomunikasi. Pribadi yang dewasa dalam berkomunikasi adalah pribadi yang sungguh-sungguh mampu memerhatikan syarat-syarat dalam berkomunikasi. Selain itu dewasa juga adalah pribadi yang sungguh-sungguh mampu mengungkapkan kontrak sosialitasnya dalam kehidupan konkrit.

\section{Simpulan dan Saran}

Manusia adalah makhluk sosial dan makhluk komunikatif. Menyadari hakikat ini, manusia mesti mampu membangun relasi dengan orang yang ada di sekitarnya. Relasi ini tentu didasarkan pada komunikasi yang baik agar relasi itu pula dapat terjalin dengan baik. Dalam membentuk komunikasi yang baik mengandaikan setiap pribadi memahami beberapa kriteria dalam komunikasi. Pribadi ynag mampu berkomunikasi ialah pribadi yang dialogal, pribadi yang memiliki sifat utuh dan otentik, pribadi yang terbuka, pribadi yang disiplin, pribadi yang mampu melihat dan memahami hal-hal yang menyebabkan proses komunikasi tidak dapat berjalan dengan lancar, baik, dan harmonis. Alat teknologi adalah ciptaan manusia karena berkembangnya pendidikan dan pengetahuan. Alat teknologi yang merupakan hasil dari pemikiran manusia, sesungguhnya bersifat netral, yaitu tidak memberikan pengaruh terhadap kehidupan para penggunanya yaitu manusia, apalagi sampai memengaruhi hakikat dasar manusia yaitu sosialitas. Namun, sifat kenetralan alat teknologi diubah atau direnggut oleh para penggunanaya yaitu manusia. Ketika manusia menggunakan alat teknologi, maka secara tidak langsung alat teknologi itu memiliki pengaruh terhadap kehidupan para penggunanya sendiri. Pengaruh tersebut ada yang bersifat positif dan ada pula yang bersifat negatif. Dampak positifnya ialah pertama, memiliki banyak teman dan kenalan. Kedua, mampu membangun relasi dengan siapapun dan dimana pun keberadaan orang tersebut. Ketiga, membuat manusia yang jauh terasa dekat. Keempat, meningkatkan sikap kepekaan sosial terhadap situasi dunia. Dampak negatifnya ialah: pertama, melemahnya sosialitas manusia. Kedua, membuat manusia yang dekat terasa jauh. Ketiga, mampu mencuci atau memengaruhi kepribadian seseorang yaitu terciptantya suatu mentalitas instan yang membuat manusia kehilangan hakihat dasarnya. Keempat, membuat dan menciptakan revolusi dalam berkomunikasi, apalagi setelah muncul dan berkembangnya internet. Maka, terjadi interaksi yang begitu memengaruhi kehidupan sosial.

Perkembangan alat teknologi, tentu saja membawah perubahan yang besar dalam segala sektor, terutama menyangkut manusia yang menggunakan alat teknologi tersebut yang sebelumnya lebih bersifat audiovisual kepada teknologi yang bersifat digital. Secara perangkat umumnya tidak terlalu berubah, namun mengalami perubahan pada manusia yang menggunakan alat teknologi, cara penggunaannya yang tentunya mesti memberikan suatu pengetahuan yang cukup penting bagi sosilaitas setiap pribadi.

\section{Daftar Pustaka}

Harahap, Reni Agustina. 2019. Ajaran Komunikasi Kesehatan. Jakarta: Prenada Media.

Harjana, M. Agust. 2003. Komunikasi Intrapersonal dan Interpersoanl. Yogyakarta: Kanisius.

Hendropuspito. 1983. Sosiologi Agama. Yogyakarta: Kanisius.

Ibda, Hamidulloh. 2018. Filsafat Umum Zaman Now. Pati: CV Kataba Group.

Imrah, Muhamad. 1999. Islam dan Keaanan Sosial. Jakarta: Gema Insani Press.

Irawan, dan Indradin. 2016. Starategi dan Perubahan Sosial. Yogyakarta: Depublish.

Lim, Francis. 2008. Filsafat Teknologi. Yogyakarta: Kanisius.

Maliki, Zainuddin. 2018. Rekonstruksi Teori Sosial Modern. Yogyakarta: Gajah Mada University Press.

Noperman, Feri. 2020. Pendidikan Sains dan Teknologi. Bengkulu: Universitas Bengkulu Press. Raharjo, Agus. 2009. Sosiologi SMA IPS. Yogyakarta: Pustaka Widyatama.

Riyanto, Armada. 2013. Menjadi-Mencintai: Berfilsafat Teologi Sehari-hari. Yogyakarta: Kanisius. 2011. Aku dan Liyan: Kata Filsafat dan Sayap. Malang: Widya Sasana Publication. 
Jurnal Filsafat Indonesia, Vol 4 No 2 Tahun 2021

ISSN: E-ISSN 2620-7982, P-ISSN: 2620-7990

2018. RELASIONALITAS: Filsafat Fondasi Interpretasi: Aku, Teks, Liyan, Fenomen. Yogyakarta: Kanisius.

2009. Politik, Sejarah, Identitas, Postmodernitas. Malang: Widya Sasana Publication.

Sugiyono, Leo. 2015. Hidup di Era Digital. Yogyakarta: Kanisus. 